\title{
GCU
}

Glasgow Caledonian

University

University for the Common Good

\section{Representative bureaucracy: does female police leadership affect gender-based violence arrests?}

Johnston Miller, Karen; Houston, John

Published in:

International Review of Administrative Sciences

DOI:

$10.1177 / 0020852315619222$

Publication date:

2018

Document Version

Author accepted manuscript

Link to publication in ResearchOnline

Citation for published version (Harvard):

Johnston Miller, K \& Houston, J 2018, 'Representative bureaucracy: does female police leadership affect gender-based violence arrests?', International Review of Administrative Sciences, vol. 84, no. 1, pp. 3-20. https://doi.org/10.1177/0020852315619222

\section{General rights}

Copyright and moral rights for the publications made accessible in the public portal are retained by the authors and/or other copyright owners and it is a condition of accessing publications that users recognise and abide by the legal requirements associated with these rights.

Take down policy

If you believe that this document breaches copyright please view our takedown policy at https://edshare.gcu.ac.uk/id/eprint/5179 for details of how to contact us. 


\title{
Representative Bureaucracy:
}

\section{Does Female Police Leadership affect Gender Based Violence Arrests?}

\author{
Karen Johnston and John Houston
}

\begin{abstract}
Representative bureaucracy theory postulates that passive representation leads to active representation of minority groups. This paper investigates the passive representation of female police officers at leadership levels and the active representation of women vis-à-vis gender based violence arrest rates in the UK. Much of the extant research on representative bureaucracy is located at street-level with evidence showing that discretionary power of minority bureaucrats can lead to active representation. This paper is focused on leadership levels of a public bureaucracy. The empirical research is based upon a panel dataset of female police officers as an independent variable and gender based violence arrest rates as a dependent variable. The analysis reveals that there is little evidence of active representation of women by female police leadership.
\end{abstract}

\section{Introduction}

There is much research on representative bureaucracy often demonstrating the link between passive and active representation. According to Mosher (1982) passive representation refers to the extent of demographic similarities between bureaucrats and the citizenry. Active representation is when a bureaucrat pursues the interests and desires of those whom they represent (Mosher, 1968:11). The research has sought to explain how and when passive leads 
to active representation for minority groups. This study seeks to add to the body of research by investigating representative bureaucracy at leadership levels of a public bureaucracy as many studies focus on bureaucrat-client relationship at street-level engagement. Furthermore, much of the research is on African-Americans and Latinos as minority groups within the US context. Research which has been conducted with regards to female representation is often located in distributive and welfare public sector organisations such as health, education and social care where there is an over-representation of women. There are fewer studies which have been conducted within organisations where there is no tradition of high levels of female employment.

The study therefore investigates the passive and active representation of women in English and Welsh police forces in the UK. Specifically, the study investigates empirically through regression modelling the relationship between the passive representation of women in leadership positions of the 43 police forces, and whether there is an active representation of women in the policy outcomes of gender-based violence. In other words the research involves examining the distribution of a demographic group (women as a minority group) within the police service and whether this has an effect on representing the interests of women through increased arrest rates of gender-based violence.

\section{Gendered Bureaucracy: The Police}

Despite increasing numbers of female employment in the UK public sector (53\%) with $36 \%$ employed in senior managerial positions, many women are employed in lower level administrative positions and most are on part-time employment contracts (Office of National Statistics, 2013a). There is evidence of vertical occupational gender segregation with few 
women in senior positions as well as horizontal occupational segregation with women concentrated in stereotypical feminine careers such as education, health and social care (Guy and Newman, 2004; McTavish and Miller, 2006; Human Rights and Equality Commission, 2011). The police have historically had low levels of female employment. Currently, in England and Wales, women represent $27.3 \%$ of the total police force (Home Office; 2013b).

The patterns of occupational gender segregation in organisations lay arguably in social construction of gender identity and socialisation. Gender identity and the social construction of sex in society are present in public bureaucracies as it recruits human resources from society. Duerst-Lahti and Kelly (1995) argue that gender and power permeates all facets of human interaction and operates within society and institutions with men controlling social, political and economic institutions. Thus, the reality for many women in public bureaucracies is that gender and power relations are patriarchal (Duerst-Lahti and Kelly 1995; Nicolson 1996; Mazur 2002; Savage and Witz 1992; Stivers 2002). A continuum of this argument is that masculinity is therefore valued in society and in organisations (Duerst-Lahti and Kelly 1995). The masculine attributes valued in organisations include agentic skills such as decisiveness, competitiveness, aggressiveness, assertiveness, controlling, confidence, ambition, dominance, forcefulness, independence, drive, risk-taking, etc. (Eagly and Johannesen-Schmidt, 2001). This manifests in vertical occupational gender segregation with men more likely to be in position of power and leadership, and in terms of horizontal occupational segregation women are more likely to be found in stereotypical feminine professions such as caring roles and sectors such as health and education (Guy and Newman, 2004). 
The police service is a public bureaucracy which is characterised as valuing masculinity (Fielding, 1994; Brown, 1998; Dick and Jankowicz, 2001; Kiely and Peek, 2002; Davies and Thomas; 2003). This is often referred to as a 'canteen culture' which promotes masculine attributes with glorification of aggression and promotion of a cult of masculinity (Waddington, 1999; Dick and Jankowicz, 2001). It is argued that the organisational police culture is 'threatened' by the presence of femininity and hence women often face discrimination, sexism and gender segregation in the police force (Waddington, 1999; Brown, 1998; Dick and Jankowicz, 2001). The police service has a high degree of cohesion and solidarity given the risk involved in the profession (Hahn, 1971; Waddington, 1999; Dick and Jankowicz, 2001; Kiely and Peek, 2002). The organisational socialisation is consolidated through formal (e.g. hierarchy, rules, standard operating procedures, etc.) and informal means (e.g. rituals, jokes, socializing, etc.) (Kiely and Peek, 2002). The police profession reflects and projects a fraternal support and solidarity which reinforces police culture often excluding 'others' (Wilkins and Williams, 2008; Dick and Jankowicz, 2001). Women, in order to survive within this culture, often assimilate to the masculine culture (Holdaway and Parker, 1998). According to Wilkins and Williams (2008) the socialisation of police officers are determined by work experience and peers rather than an officer's predisposition. Organisational socialisation is described as the process by which members of an organisation learn the required behaviour and supportive attitudes needed to be recognized as a member of the organisation (ibid). The result is long term internalization, depending of the length of service, and action congruence with organisational values and members (ibid). In their study of police racial profiling, Wilkins and Williams (2008) found that organisational socialisation superseded individual socialisation with black police officers engaged in racial profiling of minorities in the community. Similarly, Lasley et al (2011: 477) found that '...through socialisation processes within the organisation, minority officers who do hold different 
perceptions of their policing role prior to being employed as a police officer may eventually abandon these attitudes in favour of more traditional outlooks as the result of conforming or being socialized into the traditional police culture'. Furthermore, those police officers who do not conform to the organisational culture are often marginalized and ostracised (ibid).

The next section of the paper explores the theory and conceptualization of representation in public bureaucracies which serves as a framework for the current study.

\section{Representative Bureaucracy Theory}

Mosher (1982) in terms of the theory of representative bureaucracy distinguished between passive and active representation. Passive representation occurs when bureaucracy includes individuals from specified groups such as women, racial and ethnic minorities within its ranks (Bradbury and Kellough, 2011). The bureaucracy therefore has the same demographic origins as the population it serves (Riccucci and Saidel, 1997). A bureaucracy is passively represented to the extent that it employs minorities and women in numbers proportionate to the share of the population (ibid). Active representation is when a bureaucrat, consciously or unconsciously, ensures that the interests of individuals who share their group or demographic identity is not over-looked in policy decision making (Bradbury and Kellough, 2011). Thus, active representation is concerned with how representation influences policy making and implementation (Wilkins, 2006), and advocacy by bureaucrats of citizens, who share the same demographic and social background, making policy decisions that benefit these citizens (Hindera, 1993; Keiser et al, 2002; Sowa and Seldon, 2003).

Thus, the more demographically representative a bureaucracy is in terms of passive representation, the more likely it will make decisions which benefit the relevant demographic 
group (Thielemann and Stewart, 1996). Furthermore, the policy and decision making of individual bureaucrats of specific demographic and social backgrounds is influenced by socialisation experiences and the development of values, attitudes and opinions (Saltzstein, 1979; Meier, 1993; Bradbury and Kellough, 2007). Meier and Nigro (1976:458) argued that the attitudes and values of bureaucrats are determined by their social environment and when bureaucrats and the public share value orientations then bureaucrats will pursue and advocate courses of action for the public.

Representative bureaucracy research has demonstrated a link between passive and active representation and the factors which affect the translation of passive into active representation (see for example Meier, Stewart and England, 1990; Meier and Stewart, 1992; Meier, 1993; Meier, Wrinkle and Polinard, 1999; Hindera, 1993; Hindera and Young, 1998; Thielemann and Stewart, 1996; Keiser et al, 2002; Seldon, 1997; Seldon, Brudney and Kellough, 1998; Sowa and Seldon, 2003; Bradbury and Kellough, 2007). Much the research demonstrated that: (1) attitudes and values as opposed to the adoption of organisational norms through socialization; (2) opportunities for bureaucratic discretion; and (3) value congruence of minority bureaucrats with clients, as opposed to organisational congruence, are important factors in the translation of passive to active representation.

A study, relevant to this paper is Keiser et al's (2002) research of women as a minority group in the education sector. The research established conditions under-which the passive representation of women in the education sector leads to the active representation through better test performance of girls (ibid). They found that in schools with more female administrators and female teachers, there were higher test scores and advance placement rates for girls (Keiser et al, 2002:562). Keiser et al (2002) argued that the institutional context and 
structure of a public bureaucracy mattered and enabled active representation. Moreover, the bureaucrat had to have discretion to affect implementation and that the policy issue had to be salient to women as the minority demographic group. Thus, for female bureaucrats a policy issue which enables them to identify with females as clients or recipients of a public service, makes active representation more likely. A gender policy issue is when: (1) the policy directly benefits women as a class; (2) the gender of the bureaucrat changes the clientbureaucratic relationship; or (3) the issue is identified as a women's issue by the political class (ibid; also see Mazur, 2002). Thus, the gender of the bureaucrat influences the clientbureaucratic relationship particularly when the bureaucrat has discretion to act in the interest of women (Keiser et al, 2002:556).

A further condition for representation is whether the institutional and context factors of the public bureaucracy have socialized individual bureaucrats to adopt the organisational values (Keiser et al, 2002). Thus, a more hierarchical organisation may depersonalize relationships making bureaucrats less likely to identify with groups outside the bureaucracy (Keiser et al, 2002; Ferguson, 1984). Keiser et al (2002: 557-562) found, in terms of institutional context, that representative bureaucracy worked better for fenales in less hierarchical organizations. Keiser et al (2002:563) conclude that 'for those seeking to increase active representation on the basis of gender, attention must be paid to not only increasing overall passive representation but also the structure of the organisation and the representation at upper levels of the organisation.' The current study therefore seeks to explore passive and active representation at the upper echelons of a public bureaucracy.

Kim (2003) investigated the representation of women, African-Americans and Hispanics within the US Senior Executive Service (SES). The dependent variable or policy output to 
measure active representation was the allocation of line-item budgets which would benefit women and minorities in the presidential request budget for the period 1979 to 1999 . Kim (2003:556) found that in this case passive representation was slightly linked to active representation. Moreover, passive representation was necessary but not sufficient; since organisational socialisation, recruitment processes, organisational rules and peer pressure restrain bureaucrats of certain demographics and social backgrounds from exercising active representation (ibid).

Dolan (2001) found that the policy preferences of women in the SES were congruent with those of women as a minority group, suggesting that organisational socialisation did not affect SES from actively representing women. In a later study, Dolan (2004:305) argued that distributive agencies were more conducive to female leadership and women succeeded up the career ladder in these organisations by adopting strategies which worked for men. Another study by Rehfuss (1986) on the representation of women and minorities in executive positions of the California career civil service found women and minorities appear to share a 'management ideology' with their white male counterparts. This ideology is developed during organisational socialisation and works against active representation (Rehfuss, 1986:459). Other research which focused on women as a minority group was undertaken by Wilkins (2006), Wilkins and Keiser (2006) and Bowling et al (2006). In the former studies the researchers found that female child support enforcement supervisors provided active representation to female clients who directly benefitted from increase child support collections. In the latter study the researchers found that women were 'cracking the glass ceiling' with passive representative (including attributes of social and demographic origins and attainments of education, organisational experience and professionalism) as necessary for active representation (Bowling et al, 2006:833-834). It therefore appears that in gendered 
policy areas organisational socialisation and context are as important in affecting active representation for women.

Of relevance to this paper are two studies on the passive representation of women in the police and active representation in terms of beneficial outcomes for women as victims of gender based violence. The first study, conducted by Meier and Nicholson-Crotty (2006), found that a larger percentage of female police officers were associated with a greater willingness among women as clients to report sexual assaults. Furthermore, there was evidence of active representation with higher sexual assault arrest rates by female police officers. They concluded that female police officers shared a set of values about the seriousness of rape because they had a common set of gender related experiences (Meier and Nicholson-Crotty, 2006:858). A similar study by Andrews and Johnston Miller (2013) demonstrated that where there were higher levels of passive representation for women at street-level in English police forces there was a higher arrest rate for domestic violence. Another study which focused on law enforcement as a policy area was the passive representation of African-Americans and Latinos in the San Diego Police Department and the racial profiling in the case of vehicle stops (Wilkins and Williams, 2008). Of significance was the finding that as the presence of black police officers increase so does the racial disparity in vehicle stops (Wilkins and Williams, 2008:660). Moreover, the researchers found that in a bureaucracy, such as the police, where there are high levels of formal and informal organisational socialisation, it is less likely that active representation will take place (ibid). Wilkins and Williams (2008) findings support the contention that institutional context affects whether passive representation leads to active representation. A further study by Andrews et al (2014) of female representation in the English fire service showed once again that passive leads to active representation at street-level with increased representation resulting in 
improvements in organisational performance. However, there was less evidence that increased representation of women at senior levels of the fire service lead to active representation (ibid).

\section{Representative Bureaucracy Research: A Review}

Much of the studies of representative bureaucracy are within the US context with less research in other national contexts. Moreover, much of the research tends to focus on African-Americans and Latinos as minority groups with a few exceptions focusing on women as a minority group. The research that has focused on the women and representative bureaucracy tend to be within public bureaucracies where there are relatively higher levels of female passive representation. These studies, often in welfare and education sectors, may be measuring the effects of horizontal occupational gender segregation with women concentrated in these sectors. There is less research which explores the passive and active representation of women in public bureaucracies which do not have historically high levels of female employment such as law enforcement. According to Bradbury and Kellough (2011:160) certain public bureaucracies with larger proportions of women and/or other minorities in decision making roles are more likely to produce outcomes in the interest of the women and/or minorities than similar organisations with fewer women and/or minorities. Much of the research tends to examine street-level bureaucratic behaviour given the variable of discretionary power at that level. There is relatively less research with regards to women in senior, leadership positions with the few exceptions in the aforementioned section.

The extant research provides evidence that active representation is not only affected by the passive representation within a bureaucracy, it is also affected by the organisational context 
of hierarchy and socialisation, opportunities for discretion and rule compliance. Furthermore, Bradbury and Kellough (2011) assessed the cumulative evidence of representative bureaucracies and concluded that there is an ecological fallacy in that behaviour observed at a group level are aggregated to hold for all individuals who belong to that group. They argue that there is a need for a new stream of academic research in public administration where there is a disaggregation of data. Furthermore, that the co-production effects of policy outputs are investigated. In other words, where bureaucrats and clients may have independent effects on each other. An example of this is when female victims report sexual assaults they are more likely to do so in the presence of a female police officer. The female officer may therefore not necessarily be actively representing the victim, but the victim is attaching gendered assumptions to the bureaucratic-client relationship. This may explain the higher arrest rates by female police officers for sexual assaults against women (see Meier and Nicholson-Crotty, 2006).

This study therefore attempts to disaggregate data to better understand the passive representation of senior female police officers and the active representation of women. The study seeks to contribute to representative bureaucracy research in the following respects: (1) the focus on women as a minority group; (2) within a context other than the US for external validity purposes; (3) a disaggregation of organisational structure and hierarchy by examining the representation of senior female bureaucrats; (4) the investigation of the police service as a masculine organisational context and non-traditional public bureaucracy for female employment; and (5) to disaggregate the effects of the co-production of policy outputs in that there is no interaction between a senior female police officer and victim of sexual assault at the arrest level. 


\section{Data and Research Method}

The research involved the collation of a dataset consisting of: police force area size (hectares); number of male and female senior officers; the number of gender based violence (GBV) arrests; and number of household per police officer for England and Wales. The data was collected from the Home Office, Office of National Statistics, the British Association of Women Police and the Crime Survey for England and Wales.

'Seniority' is defined here as ranks from Chief Inspector up to Chief Constable as they are concerned with strategic resourcing and deployment, as well as setting policy within the area. GBV was categorised, using police data and classification, as crimes including rape, domestic abuse, sexual assault, indecent assault, sexual exploitation, abduction, and unlawful sexual intercourse and sexual activity against women and female children. Where the sex of the victim could not be determined (as in the case of recorded crimes of prostitution) the crime was excluded from the dataset. The data was collected for the years 2002 to 2011 as: it was consistent and standardized for that period; offers an almost ten year period of panel data for analysis; and in 2012 elected police commissioners were introduced in England and Wales which would impact on the discretionary capacity of senior officers' in decision making.

England and Wales are divided into 43 separate police force areas, each with its own separate command and control structure, though operating within a single legal system, accountable to the UK Parliament. Scotland, Northern Ireland, the Isle of Man and the Channel Islands have their own separate police authorities. These police forces are therefore not considered in this study due to their distinctive legal systems but offer an opportunity for further and 
comparative research. In addition, there are a number of pan-national forces, such as the British Transport Police and the Ministry of Defence Police, but these too are not included in this study, due to the narrow focus of their respective remits. The London Metropolitan Police Force has an extra rank within its hierarchy (Commander) to help it account for the sheer size and particular issues it faces as a capital city and is included in the study given the importance of the force in service delivery within a large metropolitan area.

England and Wales' police forces have remained relatively stable in structure since the last major reorganisation in 1974. There is variation in the physical areas covered by the various forces, population contained within each police force and population densities ${ }^{\mathrm{i}}$. There is however more uniformity in household density. Thus, the size of each force, each area's population and the number of households per officer (hpo) are included in the analysis. We observe a large degree of variation between the areas, ranging from 102.5 hpo (London Met) to 239 hpo (Lincolnshire) with an overall average of 162.2 hpo (Metropolitan Force). The areas do not structure themselves internally in the same way with some variation in the percentage of forces in senior ranks observed.

Thus, in order take into account these variations and to measure the effect of the presence of women at senior levels of English and Welsh police forces on the GBV arrest rates, a number of single-equation, regression-based models were constructed and tested. As data for more than one year were available for each of the 43 areas, it was possible to assemble a panel dataset, and from it to construct panel-based models. This has the considerable attraction of being able to estimate the effect of unobserved area-level characteristics that may affect the dependent variable, and thus to allow a clearer estimate of the common effect of, for instance, the number of female police officers in any area, to be obtained ${ }^{\mathrm{ii}}$. There may be significant, 
unobserved differences between the areas (e.g. male attitudes to women). Rather than seek variables that may reflect these differences, this heterogeneity can, in effect, be filtered away into a 'personal constant' term. We are, in effect, estimating models with this general form:

$$
y_{i t}=\alpha+X_{i t}^{\prime} \beta+\left(\mu_{i}+v_{i t}\right)
$$

$y_{i t}$ is the 'outcome' variable of interest (the dependent variable), $\mathrm{X}_{\text {it }}$ is a matrix of observed independent variables believed to cause the outcome (GBV arrests) pertaining to each area, $\mu_{i}$ is a fixed-effects constant, accounting for the unobserved heterogeneity and $v_{i t}$ is a residual term. Note the use of the 'it' subscript, where ' $i$ ' denotes the area and ' $t$ ' the year in which the data was observed. Only the personal constant, $\mu_{i}$ is assumed to be unchanging over the period spanned by the data. The above model is a one-way error component regression model, which was during our analysis enhanced to a two-way error component regression model, by explicitly accounting for time in the regression ${ }^{\mathrm{iii}}$ :

$$
y_{i t}=\alpha+X_{i t}^{\prime} \beta+\left(\mu_{i}+v_{i t}+\lambda_{t}\right)
$$

$\lambda_{t}$ being a year dummy included to capture the effects of time on the independent variable.

Thus, for the purposes of this study the dependent variable is the number of recorded GBV arrests made in each area between 2002 and 2011. The following independent variables were included in separate models (except for the two-way error component specification):

1. The number of senior female officers in post in the year. Should senior female officers have significantly different policy priorities to their male counterparts (at least in relation to GBV), then this would manifest itself in the associated $\beta$ coefficient.

2. The number of senior female officers in post in the previous year ('Lag'). It might be expected that it will take time for senior officers to have an impact on GBV policies. 
Accordingly, the number at these levels in the 12 months prior are included in order to determine what, if any, lagged effect on the number of GBV arrests there may be (see Andrews and Johnston Miller, 2013).

The inclusion of either one of these variable in separate models allows us to determine if there is an 'immediate' effect upon GBV numbers from the presence of women at ACPO level, or whether there is takes more time for their presence to be felt.

The variables of police force size, composition, area size, population density, household density and people per officer were controlled in the study. The models were estimated using Generalized Least Squares (GLS), using STATA, given the presence of significant heteroskedasticity in the error terms.

According to Rehfuss' (1986:454) important decisions are made or influenced at senior levels and the interests of women increase as they ascend the hierarchy. The research sought to demonstrate that women at senior levels would act in the interests of women as victims of GBV by observing an increase in GBV arrests. Thus, based on representative bureaucracy theory, the hypothesis is:

The higher the number of senior female police officers (passive representation), the higher the number of gender based violence arrest (active representation) per police force. 


\section{Findings}

Figure 1 illustrates that the population of England and Wales rose steadily through the period, while the total number of arrests made each year also rose from 2002 to 2007, though declined thereafter. The total and relative number of GBV arrests rose from 2002 to 2003; falling thereafter (see Figure 2). The proportion of arrests that relate to GBV account for $2.6 \%$ of all arrests, on average. There are three observations to make about GBV arrests. Firstly there is a decline in relation to the proportion of all arrests, secondly from 2003 to 2009 there is a variance in GBV arrests and the proportion of all arrests, and thirdly there is a 'structural break' during the years 2007 and 2008 where GBV arrests steadily begin to increase. This is mostly likely an extraneous variable (e.g. the onset of the global financial recession) and the subsequent analysis attempts to control for it. Thus, in Table 1 we have categorized the analysis for the entire period (2002-2011) and separately for the 'before' and 'after' sub-periods, 2002-2007 and 2008-2011.

[Insert Figures 1 and 2; Table 1 here]

Table 1 illustrates that the more female officers present at senior levels, the less the number of GBV arrests made, though this appears only true prior to 2008. There is also no evidence of a significant time 'lagged' effect. As an indication of the extent to which the number of GBV arrests is lower than it might otherwise have been, we can estimate that, with 35,000 GBV arrests per annum over 43 police forces (815 per force, per annum), an extra senior female officer would reduce the number by approximately $2.5 \%$. Furthermore, the more officers a force has, the more GBV arrests there will be. On average, there is one more GBV arrest for every four extra officers (FTE), deployed. There appears to be more of a correlation between number of GBV arrests and resourcing of the police force (number of FTE officers 
and officers per household). Thus, the hypothesis is not proven. On the contrary, the study found that an increase in the presence of senior female police officers saw less GBV arrests for the police force. Female police leadership was not actively representing women as victims of GBV.

For the specification that includes the number of female ACPOs in post in the years the GBV arrests were made, it can be concluded that the more female officers there were at senior levels, the fewer the number of GBV arrests made. However, this effect appears to apply only during the first sub-period (2002-7), with a reversal in the effect from 2008 onwards (i.e. more female ACPOs leads to more GBV Arrests). The specification that considers the number of female ACPOs in post the year before the arrests were made, reveals an apparently insignificant effect over the whole period of the study. This, however, masks a similar negative effect in 2002-7, changing to a smaller, positive effect from 2008 onwards.

Although this paper is concerned about (female) leadership in the Police, it is worth noting that the greater the ratio of female to male officers a force has, the lower will be the number of GBV arrests. The effect, while always negative, slows significantly from 2008 onwards, indicating, perhaps, that some critical mass of female officers had already been achieved by that time.

It can also be seen that the more officers a force has, the more GBV arrests there will be. On average, there is one more GBV arrest for every four extra officers (FTE), deployed. There is also a positive relationship between GBV arrests and the average number of households per Officer. 


\section{Discussion}

The research is significant as it found that the passive representation of women in senior positions may not necessarily translate into active representation. This is counter-intuitive to the theory of representative bureaucracy.

There are possible explanations for this finding based on extant research. The first explanation is consistent with the Keiser et al (2002) study which found that organisational structure and culture may mediate the effects of active representation. Arguably women, in order to reach senior career ranks within a hierarchical organisational structure, as is case in the police service, would have to devote a considerable period of time within the organisation and in order to be promoted meritoriously through the ranks of the organisation structure. It could be argued that female police officers assimilated to the masculine organisational culture (see Hahn, 1971; Waddington, 1999; Brown, 1998; Dick and Jankowicz, 2001; Kiely and Peek, 2002). As Lasley et al (2011) argues socialisation processes within the police may see minorities abandon congruent values with minorities and conform to the organisational culture. Thus, similarly to Wilkins and Williams' (2008) research which found that organisational socialisation in the police may make it less likely for active representation to take place.

A second explanation for the findings is that female leadership has no effect on active representation. This would support research which showed that active representation is more likely to take place at the level of bureaucratic-client interface. That is, at street-level where bureaucrats have discretionary power to act in the interest of clients. The explanation would substantiate the findings of Meier and Nicholson-Crotty (2006) and Andrews and Johnston Miller (2013) where active representation is evident at street-level policing because the 
female police officer had more discretionary power to act in the interests of female victims of GBV. Similarly, Kim (2003) concludes street-level bureaucrats are less subject to organisational culture and will use their discretion at this level to actively represent those who share similar demographic origins. Thus this research found that passive representation does not necessarily lead to active representation, perhaps even to the contrary within a masculine organisational culture and where there is no scope for discretion.

That said, the apparent change to a situation where the passive representation of women at Senior Levels does lead to active representation, might indicate that it is necessary for there to be a minimum critical mass of women at Senior Levels before this can happen: this, having been achieved in the English/Welsh police force at some stage between 2007 and 2008. The problem with this, however, is that it would have to have happened more or less simultaneously across all Forces (particularly the larger ones). As the tables in the Appendix indicate, the percentages of women at senior levels, and in total, varied greatly across the 43 Areas. Countering this, it might be speculated that the general awareness across England and Wales that women are becoming more generally more prevalent in the Force at all levels, may be sufficient to alter the behaviour and attitudes to GBV.

\section{Conclusion}

The study firstly contributed to representative bureaucracy theory by investigating the representation of women at leadership levels within a masculine public organisational context by disaggregating hierarchy. Secondly, the study addressed the lack of reliable national data on GBV in the UK (see Hester, 2008) and involved the collation of a dataset of the number of female police officers per police force per area in England and Wales. Thirdly, the study took up the challenge by Bradbury and Kellough (2011) to investigate organisations where there 
may not necessarily be high levels of female employment. Previous studies may have inadvertently measured the effects of horizontal occupational gender segregation where women were represented in stereotypical feminine professions and public bureaucracies such as health and education sectors.

The significance of the study is that it illuminates the organisational effects on representation where women may not necessarily be a majority in the organisation (Keiser et al, 2002). The research provided counter-intuitive evidence of representative bureaucracy theory in that: passive representation may not necessarily lead to active representation particularly when a masculine organisational context may have mediating effects; active representation is more likely at the level of client-bureaucratic interface as opposed to leadership levels; and the danger is that gains made in the passive representation of women may be eroded through organisational socialisation and act contrary to active representation outcomes. That said, the awareness that there is growing proportion of women at all levels in the organisation, may be sufficient to change the situation to one where passive representation leads to active representation.

\section{References}

Andrews, R. and Johnston Miller, K. (2013) Representative Bureaucracy, Gender and Policing: The Case of Domestic Violence Arrests. Public Administration 91(4): 998-1014. Baltagi, B.H. (2013) Econometric Analysis of Panel Data 5th ed. West Sussex: John Wiley \& Sons.

Bowling, C.J., Kelleher, C.A., Jones, J. and Wright. D.S. (2006) Cracked Ceilings, Firmer Floors, and Weakening Walls: trends and patterns in gender representation among 
executives leading American state agencies, 1979-2000. Public Administration Review 66(6):823-836.

Bradbury, M. and Kellough, J.E. (2007) Representative Bureaucracy: Exploring the potential for active representation in local government. Journal of Public administration Research and Theory 18(4):697-714.

Bradbury, M. and Kellough, J.E. (2011) Representative Bureaucracy: assessing the evidence on active representation. The American Review of Public Administration 41(2):157-167.

Brown, J. (1998) Aspects of Discriminatory Treatment of Women Police Officers Serving in England and Wales. British Journal of Criminology 38(2):265-82.

Childs, S. (2008) Women and British Party Politics: Descriptive, Substantive and Symbolic Representation. Oson: Routledge.

Childs, S. and Krook, M.L. (2009) Gender and Politics: The State of the Art. Politics 26(1):19-28.

CPS (2012) Violence against women and girls crime report 2011/12. http://www.justice.gov.uk/downloads/statistics/criminal-justice-stats/sexualoffending/sexualoffending-overview-jan-2013.pdf (accessed December 2013).

Davies, A. and Thomas, R. (2003) Talking Cop: Discourses of change and policing identities. Public Administration 81(4): 681-699.

Dick, P. and Jankowicz, D. (2001) A social constructionist account of police culture and its influence on the representation and progression of female officers. Policing: An International Journal of Police Strategies \& Management 24(2): 181-199.

Dolan, J. (2000) The Senior Executive Service: Gender, Attitudes, and Representative Bureaucracy. Journal of Public Administration Research and Theory 10(3):513-529.

Dolan, J. (2001) Women in the Executive Branch: A Review Essay of Their Political Impact and Career Opportunities. Women \& Politics 22 (4):89-104. 
Dolan, J. (2004) Gender Equity: Illusion or Reality for Women in the Federal Executive Service. Public Administration Review 64 (3):299-308.

Dometrius, N.C. (1984) Minorities and Women Among State Agency Leaders. Social Science Quarterly 65(1):127-137.

Duerst-Lahti, G. and Kelly, R.M. (eds.) (1995) Gender, Power, Leadership and Governance. Ann Arbor: The University of Michigan Press.

Eagly, A.H. and Johannesen-Schmidt, M.C. (2001) The Leadership Styles of Women and Men. Journal of Social Issues 57(4):781-797.

Ferguson, K. (1984) The Feminist Case Against Bureaucracy. Philadelphia: Temple UP.

Fielding, N. (1994) Cop Canteen Culture. In: T.A. Newburn and E.A. Stanko (eds.) Just Boys Doing Business? Men, Masculinity and Crime. London: Routledge, pp. 46-63.

Greene, W.H. (2008) Econometric Analysis 6th ed. Harlow: Pearson Prentice-Hall.

Guy, M.E. and Newman, M.A. (2004) Women's Jobs, Men's Jobs: Sex Segregation and Emotional Labour. Public Administration Review 64(3):289-298.

Hahn, H. (1971) A Profile of Urban Police. Law and Contemporary Problems 36: 449-466.

Hester, M. (2009) Who Does what to whom? Gender and domestic violence perpetrators. Bristol: University of Bristol.

Hindera, J. J. (1993) Representative bureaucracy: Further evidence of active representation in the EEOC district offices. Journal of Public Administration Research and Theory 3 (4):415-429.

Hindera, J.J. and Young, C.D. (1998) Representative Bureaucracy: The Theoretical Implications of Statistical Interaction. Political Research Quarterly 51(3):655-671.

Hofstede, G. (2001) Cultures and Consequences: Comparing Values, Behaviours, Institutions and Organisations Across Nations 2nd ed. London: Sage. 
Holdaway, S. and Parker, S.K. (1998) Policing Women Police. British Journal of Criminology 38(1):40-60.

Home Office (2013) Police Workforce, England and Wales, https://www.gov.uk/government/publications/police-workforce-england-and-wales-31$\underline{\text { march-2013/police-workforce-england-and-wales-31-march-2013 }}$ (accessed December 2013).

Human Rights and Equality Commission (2011) Sex and Power 2011, http://www.equalityhumanrights.com/uploaded_files/sex+power/sex_and_power_2011_gb 2_.pdf (accessed January 2014).

Kanter, R.M. (1977) Men and Women of the Corporation. New York: Basic Books.

Keiser, L.R., Wilkins, V.M., Meier, K.J. and Holland, C. (2002) Lipstick and Logarithms: Gender, Institutional Context, and Representative Bureaucracy. American Political Science Review 96(3):553-564.

Kiely, J.A. and Peek, G.S. (2002) The Culture of the British Police: Views of Police Officers. The Service Industries Journal 22(1):167-183.

Kim, C-K. (2003) Representation and Policy Outputs: examining the linkage between passive and active representation. Public Personnel Management 32(4):549-559.

Kingsley, J.D. (1944) Representative Bureaucracy. Yellow Springs, OH: Antioch Press.

Lasley, J.R., Larson, J., Chandrika, K. and Brown, G.C. (2011) Assessing the long-term effects of officer race on police attitudes towards the community: a case for representative bureaucracy theory. Police Practice and Research: An International Journal 12(6):474491.

Lipsky, M. (1980) Street-level Bureaucracy: Dilemmas of the Individual in Public Services. New York: Russell Sage. 
Long, N E. (1952) Bureaucracy and constitutionalism. American Political Science Review 46 (3):808-18.

Lovenduski, J. (2005) Feminizing Politics Cambridge: Polity Press.

Mavin, S., Bryans, P. and Waring, T. (2004) Unlearning gender blindness: new directions in management education. Management Decision 42(3/4):565-578.

Mazur, A.G. (2002) Theorizing Feminist Policy. Oxford: Oxford University Press.

McBride, D. and Mazur, A.G. (2010) The Politics of State Feminism. Philadelphia: Temple University Press.

McTavish, D. and Miller, K. (eds.) (2006) Women in Leadership and Management, New Horizons in Management Series Editor: Cary L. Cooper, Cheltenham: Edward Elgar.

Meier, K.J. (1975) Representative Bureaucracy: An Empirical Analysis. The American Political Science Review 69(2):526-542.

Meier, K.J. (1993) Latinos and Representative Bureaucracy: Testing the Thompson and Henderson Hypotheses. Journal of Public Administration Research and Theory 3(4):393414.

Meier, K.J. and Bohte, J. (2001) Structure and Discretion: Missing Links in Representative Bureaucracy. Journal of Public Administration Research and Theory 11(4):455-470.

Meier, K.J. and Nicholson-Crotty, J. (2006) Gender, Representative Bureaucracy, and Law Enforcement: The Case of Sexual Assault. Public Administration Review, 66(6):850-860.

Meier, K.J. and Nigro, L. G. (1976) Representative Bureaucracy and Policy Preferences: A Study in Attitudes of Federal Executives. Public Administration Review 36(4):458-69.

Meier, K.J. and Stewart, J, Jr. (1992) The Impact of Representative Bureaucracies: Educational Systems and Public Policies. American Review of Public Administration 22(3):157-71. 
Meier, K.J., Stewart, J. and England, R.E. (1990) Race, class and education: the politics of second generation discrimination. Madison: University of Wisconsin Press.

Meier, K.J., Wrinkle, R.D. and Polinard, J.L. (1999) Representative Bureaucracy and Distributional Equity: addressing the hard questions. Journal of Politics 61(4):1025-1039.

Miller, K. J. (2009) Public Policy Dilemma - Gender Equality Mainstreaming in UK Policy Formulation. Public Money and Management 29(1):43-50.

Miller, K., McTavish, D., and Pyper, R. (2006) Gender and Public Management: Education and Health Sectors. In: D. McTavish and K. Miller (eds.) Women in Leadership and Management. Cheltenham: Edward Elgar, pp. 181-203.

Ministry of Justice, Home Office and Office for National Statistics (2013) An overview of sexual offending in England and Wales, London: MoJ., Home Office and ONS.

Mosher, F. (1968) Democracy and the public service. New York: Oxford University Press.

Mosher, F. (1982) Democracy and the public service, 2nd ed. New York: Oxford University Press.

Nicolson, P. (1996) Gender, Power and Organisation. London: Routledge.

Office for National Statistics (ONS) (2013a) Civil Service Statistics, http://www.ons.gov.uk/ons/rel/pse/civil-service-statistics/2013/sty-civil-servicestatistics.html (accessed February 2014).

Office for National Statistics (ONS) (2013b) Police Workforce, England and Wales, 31 March 2013, https://www.gov.uk/government/publications/police-workforce-england-andwales-31-march-2013/police-workforce-england-and-wales-31-march-2013\#policeworkforce (accessed February 2014)

Perrot, S. (2002) Gender Professions and Management in the Public Sector. Public Money and Management 22(1):21-24.

Pitkin, H.F. (1967) The Concept of Representation. Berkeley: University of California Press. 
Rehfuss, J.A. (1986) A Representative Bureaucracy? Women and Minority Executives in California Career Service. Public Administration Review 46(5):454-460.

Riccucci, N.M. and Saidel, J.R. (1997) The Representativeness of State-Level Bureaucratic Leaders: A Missing Piece of the Representative Bureaucracy Puzzle. Public Administration Review 57(5):423-430.

Saltzstein, G.H. (1979) Representative Bureaucracy and Bureaucratic Responsibility: Problems and Prospects. Administration and Society 10(4):464-75.

Saltzstein, G.H. (1983) Personnel Directors and Female Employment Representation: A New Addition to Models of Equal Opportunity Policy? Social Science Quarterly 64(4):734-746.

Saltzstein, G.H. (1986) Female Mayors and Women in Municipal Jobs. American Journal of Political Science 30(1):140-164.

Savage, M. and Witz, A. (eds.) (1992) Gender and Bureaucracy. Oxford: Blackwell Publishers.

Selden, S.C. (1997) The Promise of Representative Bureaucracy. Armonk, NY: M. E. Sharpe.

Selden, S.C., Brudney, J.L. and Kellough, J.E. (1998) Bureaucracy as a Representative Institution: Toward a Reconciliation of Bureaucratic Government and Democratic Theory. American Journal of Political Science 42(3):717-744.

Smith, K., J. Flatley, K. Coleman, S. Osborne, P. Kaiza and S. R. (2010) Homicides, Firearm Offences and Intimate Violence 2008/2009. London: Home Office.

Sowa, J.E. and Selden, S.C. (2003) Administrative Discretion and Active Representation: An Expansion of the Theory of Representative Bureaucracy. Public Administration Review 63 (6):700-710.

Stivers, C. (2002) Gender Images in Public Administration: Legitimacy and the Administrative State. Thousand Oaks, California: Sage Publications. 
Thielemann, G.S. and Stewart, J. (1996) A Demand-Side Perspective on the Importance of Representative Bureaucracy: AIDS, Ethnicity, Gender, and Sexual Orientation. Public Administration Review 56(2):168-173.

Van Riper, P.P. (1958) History of the United States Civil Service. Evanston, IL: Row, Peterson.

Waddington, P.A.J. (1999) Police (canteen) sub-culture. British Journal of Criminology 39(2):287-309.

Walby, S. and Allen, J. (2004) Domestic Violence, Sexual Assault and Stalking: Findings from the British Crime Survey. London: Home Office.

Walby, S., Armstrong, J. and Strid, S. (2010) Physical and Legal Security and the Criminal Justice System: A Review of Inequalities. London: EHRC.

Wilkins, V. M. (2006) Exploring the Causal Story: Gender, Active Representation, and Bureaucratic Priorities. Journal of Public Administration Research and Theory 17(1):7794.

Wilkins, V. and Williams, B. (2008) Black or Blue: Racial Profiling and Representative Bureaucracy. Public Administration Review 68(4):654-664.

Wilkins, V.M. and Keiser, L.R. (2004) Linking Passive and Active Representation by Gender: The Case of Child Support Agencies. Journal of Public Administration Research and Theory 16(1):87-102.

Wilkins, V.M. and Williams, B.N. (2008) Black or Blue: Racial profiling and representative bureaucracy. Public Administration Review 68(4):654-664.

Wilson, F. (1996) Research Note: Organisational Theory: Blind and Deaf to Gender? Organisation Studies 17(5):825-842.

Wise, L.R. (2003) Representative Bureaucracy. In: B.G. Peters and J. Pierre (eds.) Handbook of Public Administration. Thousand Oaks, California: Sage, pp. 343-353. 
Table 1: Number of GBV Arrests per annum : version A $(* *$ : significant at $0.01 *$ significant at 0.05$)$

\begin{tabular}{|c|c|c|c|c|c|c|c|}
\hline & \multicolumn{6}{|c|}{ One-way error component } & \multirow{3}{*}{$\begin{array}{c}\text { Two-way error component } \\
\text { ACPO in-year and Lag } \\
\text { Full Period } \\
(2002-11)\end{array}$} \\
\hline & \multicolumn{3}{|c|}{ ACPO in-year } & \multicolumn{3}{|c|}{ ACPO Lag } & \\
\hline & $\begin{array}{l}\text { Full Period } \\
(2002-11)\end{array}$ & $\begin{array}{l}\text { 1st Period } \\
(2002-07)\end{array}$ & $\begin{array}{l}\text { 2nd Period } \\
(2008-11)\end{array}$ & $\begin{array}{l}\text { Full Period } \\
(2002-11)\end{array}$ & $\begin{array}{l}\text { 1st Period } \\
(2002-07)\end{array}$ & $\begin{array}{l}\text { 2nd Period } \\
(2008-11)\end{array}$ & \\
\hline $\begin{array}{l}\text { Number of Senior Female } \\
\text { Officers }\end{array}$ & $-23.593 *$ & $-72.540 * *$ & $23.729 * *$ & - & - & - & $-14.621 *$ \\
\hline $\begin{array}{l}\text { Number of Senior Female } \\
\text { Officers a year ago }\end{array}$ & - & - & - & -19.336 & $-82.925 * *$ & $31.393 * *$ & -7.337 \\
\hline $\begin{array}{l}\text { Ratio of Female to Male } \\
\text { Officers }\end{array}$ & $-655.359 * *$ & $-637.697 * *$ & $-295.093 *$ & $-679.521 * *$ & $-849.901 * *$ & $-395.524 * *$ & $-416.530 * *$ \\
\hline Number of Officers (FTE) & $0.248 * *$ & $0.274 * *$ & $0.217^{* *}$ & $0.238 * *$ & $0.262 * *$ & $0.217^{* *}$ & $0.248 * *$ \\
\hline $\begin{array}{l}\text { Number of Households per } \\
\text { Officer }\end{array}$ & $1592.741 * *$ & $1572.059 * *$ & $1872.820 * *$ & $1619.129 * *$ & $1730.488 * *$ & $1808.711 * *$ & $1384.106 * *$ \\
\hline Constant & -37.003 & $-67.502 *$ & $-191.771 * *$ & -17.492 & -5.620 & $-147.483 * *$ & -91.470 \\
\hline \multicolumn{8}{|c|}{ Diagnostics } \\
\hline N (43 groups) & 430 & 258 & 172 & 387 & 215 & 172 & 387 \\
\hline
\end{tabular}




\begin{tabular}{|l|l|l|l|l|l|l|}
\hline Wald Test $\left(X^{2}\right)$ & 4856.16 & 4820.14 & 2742.29 & 5984.24 & 3987.83 & 3051.94 \\
\hline
\end{tabular}

Table 1: Number of GBV Arrests per annum: version B $(* *$ : significant at $0.01 *$ significant at 0.05$)$

\begin{tabular}{|c|c|c|c|c|c|c|c|c|c|}
\hline & \multicolumn{3}{|c|}{ ACPO in-year and ACPO Lag } & \multicolumn{3}{|c|}{ ACPO in-year } & \multicolumn{3}{|c|}{ ACPO Lag } \\
\hline & $\begin{array}{l}\text { Full Period } \\
(2002-11)\end{array}$ & $\begin{array}{l}\text { 1st Period } \\
(2002-07)\end{array}$ & $\begin{array}{l}\text { 2nd Period } \\
(2008-11)\end{array}$ & $\begin{array}{l}\text { Full Period } \\
(2002-11)\end{array}$ & $\begin{array}{l}\text { 1st Period } \\
(2002-07)\end{array}$ & $\begin{array}{l}\text { 2nd Period } \\
(2008-11)\end{array}$ & $\begin{array}{l}\text { Full Period } \\
(2002-11)\end{array}$ & $\begin{array}{l}\text { 1st Period } \\
(2002-07)\end{array}$ & $\begin{array}{l}\text { 2nd Period } \\
(2008-11)\end{array}$ \\
\hline $\begin{array}{l}\text { Number of Senior } \\
\text { Female Officers }\end{array}$ & $-19.129 * *$ & $-40.880 * *$ & 6.945 & $-23.593 *$ & $-72.540 * *$ & $23.729 * *$ & - & - & - \\
\hline $\begin{array}{l}\text { Number of Senior } \\
\text { Female Officers a year } \\
\text { ago }\end{array}$ & -3.243 & $-26.970 *$ & 1.636 & - & - & - & -19.336 & $-82.925 * *$ & $31.393 * *$ \\
\hline $\begin{array}{l}\text { Ratio of Female to } \\
\text { Male Officers }\end{array}$ & $-631.357 * *$ & $-677.294 * *$ & -139.119 & $-655.359 * *$ & $-637.697 * *$ & $-295.093 *$ & $-679.521 * *$ & $-849.901 * *$ & $-395.524 * *$ \\
\hline $\begin{array}{l}\text { Number of Officers } \\
\text { (FTE) }\end{array}$ & $0.249 * *$ & $0.275 * *$ & $0.206 * *$ & $0.248 * *$ & $0.274 * *$ & $0.217 * *$ & $0.238 * *$ & $0.262 * *$ & $0.217 * *$ \\
\hline $\begin{array}{l}\text { Number of } \\
\text { Households per } \\
\text { Officer }\end{array}$ & $1490.838 * *$ & $1585.339 * *$ & $1920.876 * *$ & $1592.741 * *$ & $1572.059 * *$ & $1872.820 * *$ & $1619.129 * *$ & $1730.488 * *$ & $1808.711 * *$ \\
\hline Constant & -34.368 & -52.526 & $-222.295 * *$ & -37.003 & $-67.502 *$ & $-191.771 * *$ & -17.492 & -5.620 & $-147.483 * *$ \\
\hline \multicolumn{10}{|c|}{ Diagnostics } \\
\hline $\mathrm{N}$ (43 groups) & 387 & 215 & 172 & 430 & 258 & 172 & 387 & 215 & 172 \\
\hline Wald Test $\left(\mathrm{X}^{2}\right)$ & 1424.79 & 3365.31 & 1759.85 & 4856.16 & 4820.14 & 2742.29 & 5984.24 & 3987.83 & 3051.94 \\
\hline
\end{tabular}

Figure 1: Population and Arrests (All \& GBV) $2002-2011$ 


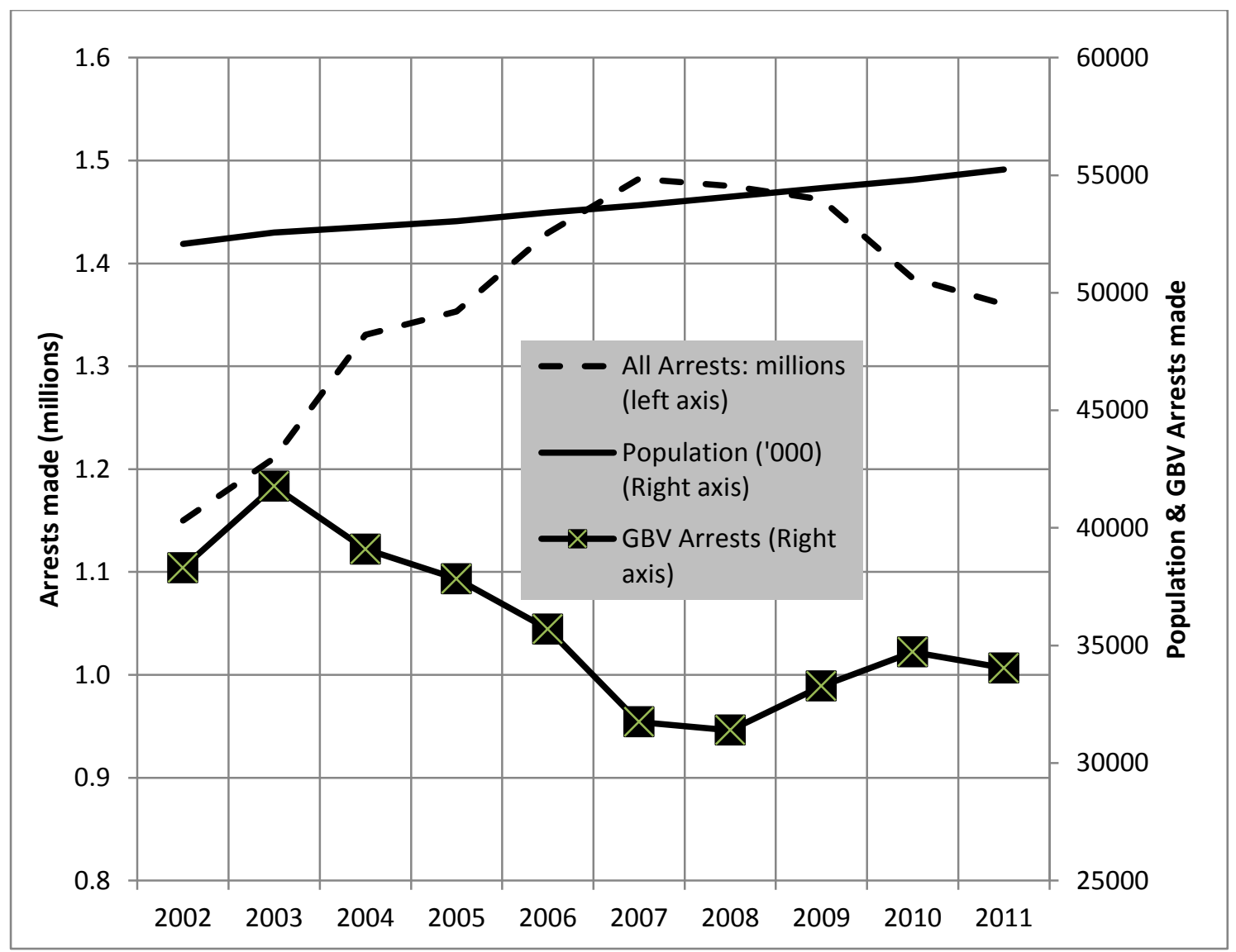

Figure 2: GBV Arrests and Arrest Rates 2002 - 2011 


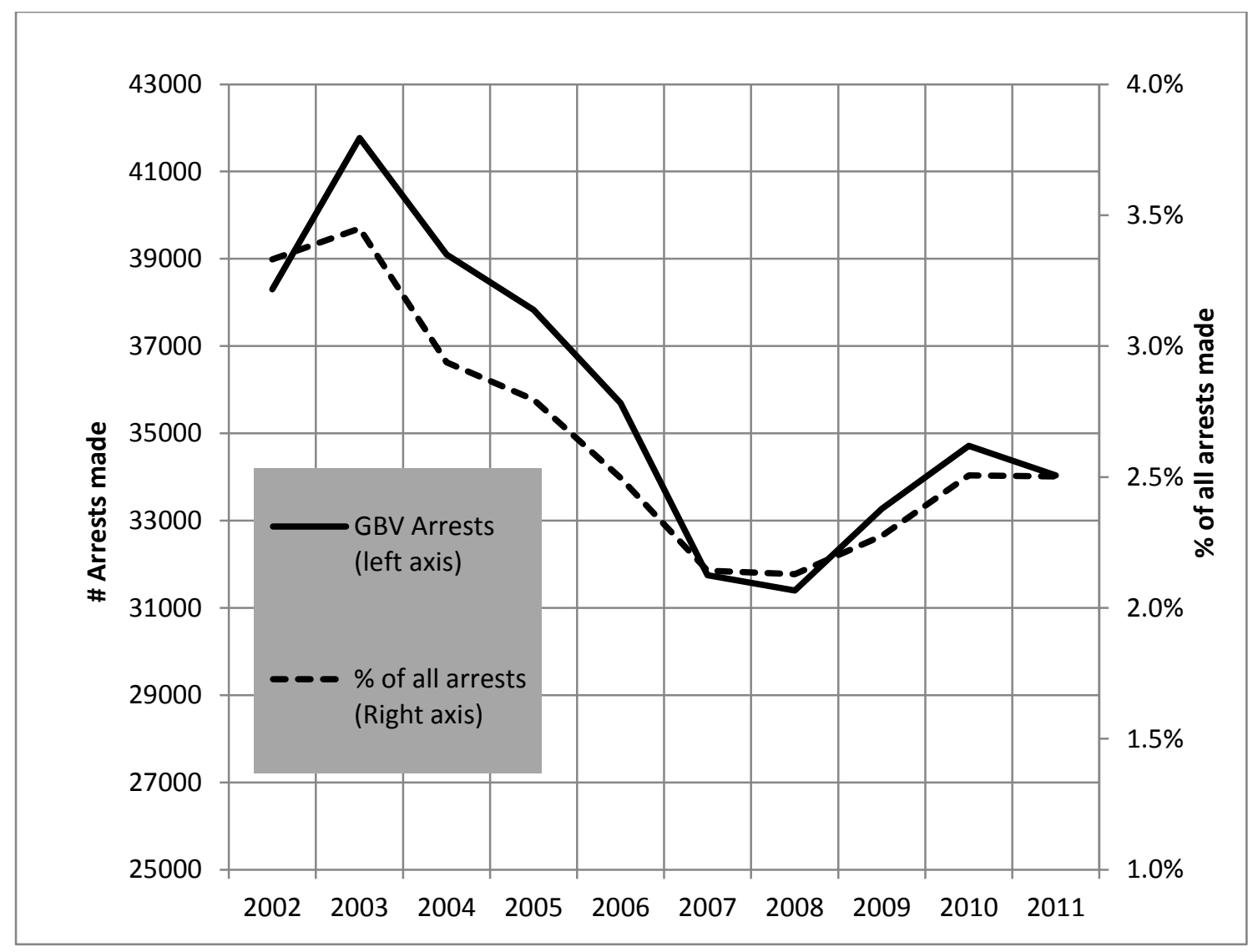


Appendix : Descriptive Data

${ }^{\mathrm{i}}$ Defined here as Population / Area in $\mathrm{km}^{2}$.
${ }_{\text {ii }}$ See Greene (2008) for example, for more details on the panel-based regression model.
iii See Baltagi (2013) for more discussion of the one- and two-way models. 